\title{
Utilization of Yeast Waste Fermented Citric Waste as a Protein Source to Replace Soybean Meal and Various Roughage to Concentrate Ratios on In Vitro Rumen Fermentation, Gas Kinetic, and Feed Digestion
}

\author{
Chaichana Suriyapha ${ }^{1}$, Anusorn Cherdthong ${ }^{1, *\left(\mathbb{D}, \text { Chanon Suntara }^{1} \text { and Sineenart Polyorach }\right.}{ }^{2}$ \\ 1 Tropical Feed Resources Research and Development Center (TROFREC), Department of Animal Science, \\ Faculty of Agriculture, Khon Kaen University, Khon Kaen 40002, Thailand; chaichana_s@kkumail.com (C.S.); \\ chanon_su@kkumail.com (C.S.) \\ 2 Department of Animal Production Technology and Fisheries, Faculty of Agricultural Technology, \\ King Mongkut's Institute of Technology, Bangkok 10520, Thailand; sineenart.po@kmitl.ac.th \\ * Correspondence: anusornc@kku.ac.th; Tel./Fax: +66-4320-2362
}

\section{check for} updates

Citation: Suriyapha, C.; Cherdthong A.; Suntara, C.; Polyorach, S. Utilization of Yeast Waste Fermented Citric Waste as a Protein Source to Replace Soybean Meal and Various Roughage to Concentrate Ratios on In Vitro Rumen Fermentation, Gas Kinetic, and Feed Digestion. Fermentation 2021, 7, 120. https:// doi.org/10.3390/fermentation7030120

Academic Editor: Ronnie G. Willaert

Received: 23 June 2021

Accepted: 16 July 2021

Published: 17 July 2021

Publisher's Note: MDPI stays neutral with regard to jurisdictional claims in published maps and institutional affiliations.

Copyright: (c) 2021 by the authors. Licensee MDPI, Basel, Switzerland. This article is an open access article distributed under the terms and conditions of the Creative Commons Attribution (CC BY) license (https:/ / creativecommons.org/licenses/by/ $4.0 /)$.

\begin{abstract}
The objective of this study was to determine the application of citric waste fermented yeast waste (CWYW) obtained from an agro-industrial by-product as a protein source to replace soybean meal (SBM) in a concentrate diet. We also determined the effect of various roughage to concentrate ratios (R:C) on the gas production kinetics, ruminal characteristics, and in vitro digestibility using an in vitro gas production technique. The experiment design was a $3 \times 5$ factorial design arranged in a completely randomized design (CRD), with three replicates. There were three R:C ratios (60:40, 50:50, and 40:60) and five replacing SBM with CWYW (SBM:CWYW) ratios (100:0, 75:25, 50:50, 25:75, and 0:100). The CWYW product's crude protein (CP) content was $535 \mathrm{~g} / \mathrm{kg}$ dry matter (DM). There was no interaction effect between R:C ratios and SBM:CWYW ratios for all parameters observed $(p>0.05)$. The SBM:CWYW ratio did not affect the kinetics and the cumulative amount of gas. However, the gas potential extent and cumulative production of gas were increased with the R:C ratio of 40:60, and the values were about 74.9 and $75.0 \mathrm{~mL} / 0.5 \mathrm{~g}$, respectively $(p<0.01)$. The replacement of SBM by CWYW at up to $75 \%$ did not alter in vitro dry matter digestibility (IVDMD), but $100 \%$ CWYW replacement significantly reduced $(p<0.05)$ IVDMD at $24 \mathrm{~h}$ of incubation and the mean value. In addition, IVDMD at $12 \mathrm{~h}$ and $24 \mathrm{~h}$ of incubation and the mean value were significantly increased with the R:C ratio of 40:60 ( $p<0.01)$. The SBM:CWYW ratio did not change the ruminal $\mathrm{pH}$ and population of protozoa $(p>0.05)$. The ruminal $\mathrm{pH}$ was reduced at the $\mathrm{R}: \mathrm{C}$ ratio of 40:60 $(p<0.01)$, whereas the protozoal population at $4 \mathrm{~h}$ was increased $(p<0.05)$. The SBM:CWYW ratio did not impact the in vitro volatile fatty acid (VFA) profile $(p>0.05)$. However, the total VFA, and propionate (C3) concentration were significantly increased $(p<0.01)$ by the R:C ratio of 40:60. In conclusion, the replacement of SBM by 75\% CWYW did not show any negative impact on parameters observed, and the R:C ratio of 40:60 enhanced the gas kinetics, digestibility, VFA, and C3 concentration.
\end{abstract}

Keywords: citric waste; yeast waste; industrial by-product; protein source

\section{Introduction}

The security of livestock feed is a fairly frequent topic of discussion in terms of quality and quantity, especially in terms of the lack of protein sources, which results in low performance. High-quality protein feed sources such as soybean meal are expensive and lead to an increase in the cost of livestock production [1]. Many researchers have attempted to look for alternative sources of protein that could help improve the production and productivity of livestock [2,3]. The utilization of agro-industrial by-products as animal feed is an interesting consideration, since it could reduce feed costs and help reduce environmental pollution [4]. 
Citric waste is a by-product of the citric acid industry and is generated from rice, corn, cassava, or cassava pulp that is fermented with Aspergillus niger [5]. The citric waste still has some nutritive value of $30-70 \mathrm{~g} / \mathrm{kg}$ DM of crude protein and contain high fiber content (861.3 g/ kg DM of neutral detergent fiber (NDF) and $197.4 \mathrm{~g} / \mathrm{kg}$ DM of acid detergent fiber (ADF), respectively) [6]. Uriyapongson et al. [6] reported that the inclusion of $10 \%$ citric waste in the diet of buffalos did not negatively affect feed intake, average daily gain (ADG), and the feed conversion ratio (FCR), whereas the digestibility was decreased with more than $10 \%$ citric waste. This might be due to the high content of fiber limiting digestion by animals, resulting in them being able to utilize only a low amount of nutrients [7]. Therefore, for the use of citric waste as animal feed, we should improve the quality by reducing the fiber composition and enhancing another nutrients, particularly the protein content.

Yeast (Saccharomyces cerevisiae) is a source of probiotics that enable a positive effect on the rumen fermentation of ruminants. It has been used as a biological method to improve the protein quality of feedstuff [8]. In ethanol production processes, the initial substrates are molasses and inoculants of the yeast $S$. cerevisiae. Yeast waste is a residue generated from ethanol production. Díaz et al. [9] reported that yeast waste contains a high content of live yeast cells (about 60-70\%). Furthermore, Cherdthong et al. [10] revealed that yeast waste contains around $264.0 \mathrm{~g} / \mathrm{kg}$ of crude protein and is rich in vitamins and minerals. Cherdthong et al. [11] found that dried yeast waste can replace up to $100 \%$ of soybean meal in animal feed with no negative effect to feed intake, feed utilization, and ruminal ecology in beef cattle. Therefore, yeast waste obtained from industrial by-products containing many live yeast cells might be beneficial for enhancing feed quality and feed utilization in animals.

The ratio of roughage to concentrate $(\mathrm{R}: \mathrm{C})$ in feeds is important for good nutrient utilization for production. Feeds have strong ties with the ecology of the rumen, ruminal bacteria, and trends of rumen fermentation [12]. Suitable amounts of concentrate can provide fiber utilization by enhancing fermentable organic matter, nitrogen, and energy sources for ruminal microbes [3]. Generally, feeding with a concentrate can provide more fermentation end-products than feeding with only roughage. Rice straw is easily obtainable from rice cultivation areas and is usually collected by farmers for feeding cattle [13]. Hence, the feeding of ruminants with rice straw and a concentrated diet that contains a high amount of protein and energy would be beneficial for ruminant productivity [14].

It was hypothesized that inoculated yeast waste obtained from industrial by-products could improve the quality of citric waste and could be used as a potential alternative protein source. Therefore, we investigated the utilization of citric waste fermented yeast waste (CWYW) obtained from agro-industrial by-products as a protein source to replace soybean meal in a concentrated diet, as well as the effect of various roughage to concentrate ratios $(\mathrm{R}: \mathrm{C})$ on gas production kinetics, rumen characteristics, and in vitro feed digestibility using an in vitro gas measuring technique.

\section{Materials and Methods}

The experimental cattle involved in this research were approved by Khon Kaen University's Animal Ethics Committee (record no. IACUC-KKU-27/64).

\subsection{Preparation of Citric Waste Fermented Yeast Waste (CWYW)}

Yeast waste was received as a by-product of ethanol production from KSL Green Innovation Public Company Limited (KGI), Nam Phong District, Khon Kaen Province, Thailand. Citric waste was obtained as a by-product of the citric acid industry from Sam Mor Farm Limited Partnership, Muang District, Udon Thani Province. Commercial grade urea and molasses were purchased from a local shop.

CWYW was prepared with the procedure that follows. First, $100 \mathrm{~mL}$ of yeast waste was added to a flask (A). Next, $20 \mathrm{~g}$ of brown sugar was weighed and dissolved in $100 \mathrm{~mL}$ of distilled water, and then $50 \mathrm{~g}$ of urea was mixed in (B). Yeast waste media solution was made by mixing $A$ and $B$ at a ratio of $1: 1$ and then flushing them for $16 \mathrm{~h}$ with air using an 
air pump at room temperature. The $\mathrm{pH}$ was adjusted to a range of 3.9 to 4.5 . After $16 \mathrm{~h}$, we transferred the yeast waste media solution and mixed it with citric waste at a ratio of $1 \mathrm{~mL}$ to $1 \mathrm{~g}$. After that, anaerobic fermentation was performed in container bottles for 14 days, followed by $48 \mathrm{~h}$ of sun-drying to obtain less than $10 \%$ moisture. The CWYW was packed in a plastic bag for subsequent use as an experimental ingredient for dietary treatment.

\subsection{Experimental Design and Dietary Treatments}

The present experiment was performed at different incubation intervals using a gas production technique. A $3 \times 5$ factorial experiment design was conducted and arranged according to a completely randomized design (CRD) with three replication runs. The experimental diets had three roughage to concentrate (R:C) ratios of 60:40, 50:50, and 40:60 with five replacing soybean meal ratios of replacement in diets (SBM:CWYW) of 100:0, $75: 25,50: 50,25: 75$, and 0:100. All of the experimental dietary samples were oven-dried at $72{ }^{\circ} \mathrm{C}$ and ground to pass a $1 \mathrm{~mm}$ sieve (Cyclotech Mill, Tecator, Sweden) for the analysis of the chemical composition and the gas production test. Experimental diets including concentrate, rice straw, and CWYW were analyzed for dry matter (DM; ID 967.03), ash (ID 492.05), and crude protein (CP; ID 984.13) content using the standard analysis of the AOAC [15]. NDF and ADF contents were determined using the procedures of Van Soest et al. [16]. Table 1 shows the diet compositions and ingredients of the concentrate, rice straw, and CWYW used in this experiment. The concentrate diets were prepared with $141.0-142.0 \mathrm{~g} / \mathrm{kg}$ of CP, which is recommended for beef cattle.

Table 1. Ingredient and chemical composition of concentrates, rice straw and citric waste fermented yeast waste used in the experiment.

\begin{tabular}{|c|c|c|c|c|c|c|c|c|c|}
\hline \multirow{2}{*}{ Item } & \multicolumn{5}{|c|}{ SBM:CWYW ${ }^{1}$} & \multirow[t]{2}{*}{$\mathrm{RS}^{2}$} & \multirow[t]{2}{*}{$\mathrm{YW}^{3}$} & \multirow[t]{2}{*}{$\mathrm{CW}^{4}$} & \multirow[t]{2}{*}{$\mathrm{CWYW}^{5}$} \\
\hline & 100:0 & $75: 25$ & $50: 50$ & $25: 75$ & $0: 100$ & & & & \\
\hline \multicolumn{10}{|c|}{ Ingredients (kg of dry matter) } \\
\hline Cassava chips & 59.3 & 58.5 & 59.5 & 58.8 & 59.7 & - & - & - & - \\
\hline Rice bran & 9.0 & 9.0 & 9.0 & 9.0 & 9.0 & - & - & - & - \\
\hline Soybean meal & 15.0 & 12.3 & 7.5 & 3.8 & 0.0 & - & - & - & - \\
\hline Palm kernel meal & 13.0 & 13.0 & 13.0 & 13.0 & 13.0 & - & - & - & - \\
\hline $\mathrm{CWYW}^{1}$ & 0.0 & 3.8 & 7.5 & 12.3 & 15.0 & - & - & - & - \\
\hline Urea & 1.3 & 1.0 & 1.0 & 0.7 & 0.8 & - & - & - & - \\
\hline Mineral premix & 1.0 & 1.0 & 1.0 & 1.0 & 1.0 & - & - & - & - \\
\hline Molasses, liquid & 1.0 & 1.0 & 1.0 & 1.0 & 1.0 & - & - & - & - \\
\hline Pure sulfur & 0.5 & 0.5 & 0.5 & 0.5 & 0.5 & - & - & - & - \\
\hline Salt & 1.0 & 1.0 & 1.0 & 1.0 & 1.0 & - & - & - & - \\
\hline & \multicolumn{9}{|c|}{ Chemical composition } \\
\hline Dry matter (g/kg) & 926 & 923 & 922 & 922 & 918 & 944 & 360 & 919 & 882 \\
\hline & \multicolumn{9}{|c|}{$\mathrm{g} / \mathrm{kg}$ of dry matter } \\
\hline Organic matter & 888 & 882 & 877 & 861 & 860 & 827 & 899 & 889 & 894 \\
\hline Ash & 112 & 118 & 123 & 139 & 140 & 173 & 101 & 111 & 106 \\
\hline Crude protein & 141 & 142 & 141 & 141 & 142 & 26 & 315 & 110 & 535 \\
\hline Neutral detergent fiber & 159 & 167 & 169 & 171 & 174 & 779 & 217 & 709 & 402 \\
\hline Acid detergent fiber & 72 & 84 & 91 & 94 & 99 & 536 & 44 & 426 & 294 \\
\hline
\end{tabular}

${ }^{1}$ SBM:CWYW = replacing soybean meal with citric waste fermented yeast waste ratio; ${ }^{2} \mathrm{RS}=$ rice straw, ${ }^{3} \mathrm{YW}=$ yeast waste, ${ }^{4} \mathrm{CW}=$ citric waste ${ }^{5} \mathrm{CWYW}=$ citric waste fermented yeast waste.

\subsection{Animals and Ruminal Inoculums Preparation}

Two male 3-year-old ruminally fistulated crossbreed (Thai $\times$ Holstein) cattle with body weights (BW) of $280 \pm 15.0 \mathrm{~kg}$ were used as ruminal liquor donors. Ruminal liquor was obtained while the animals were fed ad libitum with roughage (rice straw) and concentrate (140 g/kg CP and $805 \mathrm{~g} / \mathrm{kg}$ TDN) at 0.5\% of BW daily (6:30 a.m. and 4:30 p.m.). The cattle were housed in individual pens, and clean water and mineral blocks were freely available. The cattle were fed with the diet for $21 \mathrm{~d}$ before collecting the rumen liquor. 
From each of the cattle, $1000 \mathrm{~mL}$ of ruminal liquor was collected before feeding time in the morning. Ruminal liquor was filtered through five layers of cheesecloth and then moved to the laboratory in pre-warmed thermos bottles.

The medium was prepared using the procedures reported by Makkar et al. [17] which consisted of combining $3000 \mathrm{~mL}$ of reduced medium with $1500 \mathrm{~mL}$ of ruminal liquor from cattle (2:1; reduced medium: ruminal liquor). The medium mixture was then kept under stirring at $39{ }^{\circ} \mathrm{C}$ under $\mathrm{CO}_{2}$ with a hot plate. Each experimental bottle was filled with $40 \mathrm{~mL}$ of ruminal fluid mixture and incubated in a water bath at $39^{\circ} \mathrm{C}$.

\subsection{In Vitro Gas Production and Ruminal Fermentation Characteristics}

The gas production was measured instantly after incubation for $0,0.5,1,2,4,6,8$, $12,18,24,48,72$, and $96 \mathrm{~h}$ according to the modified procedures of Cherdthong et al. [10]. Ørskov and McDonald [18] models were used for curve fitting and analysis of the kinetics of gas as follows:

$$
\mathrm{y}=a+b\left(1-\mathrm{e}^{(-c t)}\right)
$$

where $a=$ soluble fraction from gas production, $b=$ insoluble fraction from gas production, $c=$ rate of gas production constant for the insoluble fraction $(b), t=$ incubate time, $(|a|+b)$ $=$ the potential extent of gas production, and $\mathrm{y}=$ gas produced at time ' $t$ '.

The ruminal $\mathrm{pH}$ was recorded using a digital $\mathrm{pH}$ meter (HANNA Instrument (HI) 8424 microcomputer, Singapore) at incubation times of 0 and $4 \mathrm{~h}$. The incubated ruminal liquor was divided into two parts. The first part $(20 \mathrm{~mL})$ was kept in $5 \mathrm{~mL}$ of $1 \mathrm{M} \mathrm{H}_{2} \mathrm{SO}_{4}$ and stored at $-20{ }^{\circ} \mathrm{C}$ for ammonia nitrogen $\left(\mathrm{NH}_{3}-\mathrm{N}\right)$ analysis according to the micro-Kjeldahl methods, and in vitro volatile fatty acid (VFA) concentration was performed according to the procedures of Samuel et al. [19] using high performance liquid chromatography (HPLC machine; Shimadzu LC-20A, Kyoto, Japan) equipped with an Inertsil ODS-3 C18 (250 $\mathrm{mm} \times 4.6 \mathrm{~mm}$ i.d., $5 \mu \mathrm{m}$,) column and mobile phase: phosphoric acid $25 \mathrm{mM}$, flow rate: $1 \mathrm{~mL} /$ minute, detection (UV): $210 \mathrm{~nm}$ : injection: 20 microliters (Shimadzu LC-20A, Kyoto, Japan). The second part $(1 \mathrm{~mL})$ was collected in $9 \mathrm{~mL}$ of $10 \%$ formalin for the direct counting of protozoa [20].

In vitro dry matter digestibility (IVDMD) and in vitro organic matter digestibility (IVOMD) were analyzed after incubation for 12 and $24 \mathrm{~h}$ using the procedures of Tilley and Terry [21].

\subsection{Statistical Analysis}

The data of the experiment were statistically evaluated with a $3 \times 5$ factorial arrangement according to CRD using the Proc. GLM procedure of SAS software version 9.4 (SAS Inst. Inc., Cary, NC, USA) [22]. All data were analyzed by the following equation:

$$
Y i j=\mu+A i+B j+A B i j+\varepsilon i j
$$

where: $\mathrm{Y}=$ observations; $\mu=$ overall mean; $\mathrm{Ai}=$ effect of factor $\mathrm{A}$ (R:C ratio at 60:40, 50:50, and 40:60; $\mathrm{i}=1$ to 3); $\mathrm{Bj}=$ effect of factor $B$ (SBM:CWYW ratio at 100:0, 75:25, 50:50, $25: 75$, and $0: 100 ; j=1$ to 5$), A B i j=$ the interaction effect of $R: C$ ratio and SBM:CWYW, and $\varepsilon i j=$ the residual effect. Duncan's New Multiple Range Test (DMRT) performed multiple comparisons between treatment methods [23]. Differences between mean values of $p<0.05$ were considered to represent statistically significant differences.

\section{Results}

\subsection{Dietary Chemical Composition}

Experimental dietary ingredients and chemical compositions of rice straw, concentrate, yeast waste, citric waste and CWYW are presented in Table 1. The concentrate diets were provided with almost the same protein content in each group, ranging from 141 to $142 \mathrm{~g} / \mathrm{kg}$ $\mathrm{DM}$, and urea was administered to adjust the CP content. The yeast waste's CP content was $315 \mathrm{~g} / \mathrm{kg}$ DM. The citric waste had low CP and high fiber contents (NDF and ADF) of 110, 
709 , and $426 \mathrm{~g} / \mathrm{kg}$ DM, respectively. After quality improvement, the CWYW product's CP was increased, and the fiber (NDF and ADF) value was reduced to 535, 402, and $294 \mathrm{~g} / \mathrm{kg}$ $\mathrm{DM}$, respectively.

\subsection{Kinetics and Cumulative Production of Gas}

The data obtained for the substrates analyzed from the kinetics and cumulative production of gas are shown in Table 2. The data demonstrated that the soluble fractions of gas production (a), insoluble fraction of gas production (b), rate of constants for the insoluble fraction (c), potential extent of gas production $(|\mathrm{a}|+\mathrm{b})$ and the cumulative production of gas were not affected by the interaction between the R:C ratio and SBM:CWYW ratio. In addition, the SBM:CWYW ratio did not affect the kinetics and cumulative amount of gas. However, soluble fractions of gas production (a) ranged from -3.7 to $-5.3 \mathrm{~mL} / 0.5 \mathrm{~g}$ and were decreased at the R:C ratio of 40:60 $(p<0.01)$. The value of the insoluble fraction of gas production (b) was also decreased at the R:C ratio of 40:60 $(p<0.01)$. The value of the rate of gas production (c) ranged from 0.06 to $0.08 \mathrm{~mL} / \mathrm{h}$ and was increased at the $\mathrm{R}: \mathrm{C}$ ratio of 40:60 $(p<0.01)$. The potential extent of gas $(|\mathrm{a}|+\mathrm{b})$ value and the cumulative production of gas (at $96 \mathrm{~h}$ of incubation) were increased $(p<0.01)$ at the $\mathrm{R}: \mathrm{C}$ ratio of 40:60, and the values were about 74.5 and $77.0 \mathrm{~mL} / 0.5 \mathrm{~g}$, respectively.

Table 2. Effect of R:C ratio level combined with SBM:CWYW ratio level on gas kinetics and cumulative gas at $96 \mathrm{~h}$ after incubation.

\begin{tabular}{|c|c|c|c|c|c|c|}
\hline \multirow{2}{*}{$R: C^{1}$} & \multirow{2}{*}{ SBM:CWYW ${ }^{2}$} & \multicolumn{4}{|c|}{ Gas Kinetics $^{3}$} & \multirow{2}{*}{$\begin{array}{l}\text { Cumulative } \\
\text { Gas (mL/0.5g) }\end{array}$} \\
\hline & & $\mathbf{a}$ & $\mathbf{b}$ & c & $|\mathbf{a}|+\mathbf{b}$ & \\
\hline & $100: 0$ & -3.9 & 70.4 & 0.06 & 74.4 & 74.7 \\
\hline & $75: 25$ & -3.8 & 70.2 & 0.06 & 74.0 & 73.9 \\
\hline \multirow{5}{*}{$60: 40$} & $50: 50$ & -3.7 & 70.2 & 0.06 & 73.9 & 74.0 \\
\hline & $25: 75$ & -3.8 & 70.4 & 0.06 & 74.2 & 73.6 \\
\hline & $0: 100$ & -4.0 & 70.4 & 0.06 & 74.4 & 74.3 \\
\hline & $100: 0$ & -4.9 & 69.8 & 0.07 & 74.8 & 74.8 \\
\hline & $75: 25$ & -5.0 & 69.8 & 0.07 & 74.9 & 75.7 \\
\hline \multirow[t]{5}{*}{$50: 50$} & $50: 50$ & -5.0 & 69.7 & 0.07 & 74.8 & 75.6 \\
\hline & $25: 75$ & -5.0 & 69.9 & 0.07 & 74.9 & 76.0 \\
\hline & $0: 100$ & -5.1 & 69.7 & 0.07 & 74.9 & 75.7 \\
\hline & $100: 0$ & -5.3 & 69.9 & 0.07 & 75.3 & 76.4 \\
\hline & $75: 25$ & -5.4 & 69.2 & 0.08 & 74.6 & 77.1 \\
\hline \multirow[t]{3}{*}{$40: 60$} & $50: 50$ & -5.4 & 69.5 & 0.07 & 74.6 & 76.0 \\
\hline & $25: 75$ & -5.2 & 69.5 & 0.07 & 74.8 & 75.8 \\
\hline & $0: 100$ & -5.2 & 69.7 & 0.07 & 75.1 & 76.3 \\
\hline \multirow[t]{6}{*}{ SEM } & & 0.21 & 0.26 & 0.002 & 0.30 & 1.31 \\
\hline & arison & & & & & \\
\hline & ratio & $<0.01$ & $<0.01$ & $<0.01$ & $<0.01$ & $<0.01$ \\
\hline & $: 40$ & $-3.8^{\mathrm{a}}$ & $70.3^{a}$ & $0.063^{c}$ & $74.2^{b}$ & $74.5^{\mathrm{c}}$ \\
\hline & $: 50$ & $-5.0^{b}$ & $69.8^{\mathrm{b}}$ & $0.068^{b}$ & $74.8^{\mathrm{a}}$ & $75.8^{b}$ \\
\hline & $: 60$ & $-5.3^{c}$ & $69.6^{b}$ & $0.071^{\mathrm{a}}$ & $74.9^{\mathrm{a}}$ & $77.0^{\mathrm{a}}$ \\
\hline \multicolumn{2}{|c|}{ SBM:CWYW ratio } & 0.31 & 0.58 & 0.96 & 0.40 & 0.98 \\
\hline \multicolumn{2}{|c|}{$100: 0$} & -4.6 & 70.1 & 0.07 & 74.8 & 75.9 \\
\hline \multicolumn{2}{|c|}{$75: 25$} & -4.6 & 69.9 & 0.07 & 74.5 & 75.8 \\
\hline \multicolumn{2}{|c|}{$50: 50$} & -4.7 & 69.9 & 0.07 & 74.4 & 75.8 \\
\hline \multicolumn{2}{|c|}{$25: 75$} & -4.7 & 69.8 & 0.07 & 74.6 & 75.7 \\
\hline \multicolumn{2}{|c|}{$0: 100$} & -4.8 & 69.7 & 0.07 & 74.8 & 75.6 \\
\hline \multicolumn{2}{|c|}{ Interaction } & 0.94 & 0.96 & 0.39 & 0.95 & 0.99 \\
\hline
\end{tabular}

$\overline{\mathrm{a}-\mathrm{c}}$ Value on the same row with different superscripts differ $(p<0.05) ;{ }^{1} \mathrm{R}: \mathrm{C}=$ roughage to concentrate ratio ${ }^{2}$ SBM:CWYW = replacing soybean meal with citric waste fermented yeast waste ratio; ${ }^{3} \mathrm{a}=$ the gas production from the immediately soluble fraction, $\mathrm{b}=$ the gas production from the insoluble fraction, $\mathrm{c}=$ the gas production rate constant for the insoluble fraction (b), $|a|+b=$ the gas potential extent of gas production. 


\subsection{In Vitro Digestibility}

Table 3 shows the influence of substituting SBM for CWYW in combination with the $\mathrm{R}: \mathrm{C}$ ratio on IVDMD and IVOMD. It was found that IVDMD and IVOMD did not show interaction with each other. There were no changes in IVOMD when the SBM:CWYW ratio was included. The replacement of SBM by CWYW by up to 75\% did not alter IVDMD, but $100 \%$ CWYW replacement significantly reduced $(p<0.05)$ IVDMD at $24 \mathrm{~h}$ of incubation and the mean value $(p<0.05)$. In addition, IVDMD at $12 \mathrm{~h}$ and $24 \mathrm{~h}$ of incubation and the mean value were significantly increased $(p<0.01)$ with the $R: C$ ratio of 40:60 (about 559, 701 , and $631 \mathrm{~g} / \mathrm{kg}$, respectively). Moreover, the R:C ratio of 40:60 significantly increased $(p<0.01)$ IVOMD at $12 \mathrm{~h}, 24 \mathrm{~h}$, and the mean value $(706,793$, and $750 \mathrm{~g} / \mathrm{kg}$, respectively).

Table 3. Effect of R:C ratio level combined with SBM:CWYW ratio level on in vitro dry matter digestibility (IVDMD) and in vitro organic matter digestibility (IVOMD).

\begin{tabular}{|c|c|c|c|c|c|c|c|}
\hline \multirow{2}{*}{$\mathrm{R}: \mathrm{C}^{1}$} & \multirow{2}{*}{ SBM:CWYW ${ }^{2}$} & \multicolumn{3}{|c|}{ IVDMD (g/kg) } & \multicolumn{3}{|c|}{ IVOMD (g/kg) } \\
\hline & & $12 \mathrm{~h}$ & $24 \mathrm{~h}$ & Mean & $12 \mathrm{~h}$ & $24 \mathrm{~h}$ & Mean \\
\hline & $100: 0$ & 541 & 682 & 622 & 683 & 770 & 726 \\
\hline & $75: 25$ & 542 & 676 & 618 & 675 & 773 & 724 \\
\hline \multirow[t]{5}{*}{$60: 40$} & $50: 50$ & 540 & 675 & 612 & 675 & 774 & 725 \\
\hline & $25: 75$ & 540 & 674 & 619 & 674 & 774 & 724 \\
\hline & $0: 100$ & 539 & 678 & 611 & 679 & 768 & 723 \\
\hline & 100:0 & 553 & 691 & 630 & 692 & 781 & 736 \\
\hline & $75: 25$ & 553 & 690 & 623 & 693 & 782 & 737 \\
\hline \multirow[t]{5}{*}{$50: 50$} & $50: 50$ & 551 & 688 & 621 & 692 & 781 & 736 \\
\hline & $25: 75$ & 551 & 689 & 622 & 691 & 775 & 733 \\
\hline & $0: 100$ & 551 & 688 & 622 & 691 & 775 & 733 \\
\hline & 100:0 & 560 & 704 & 634 & 709 & 792 & 751 \\
\hline & $75: 25$ & 560 & 702 & 632 & 707 & 795 & 751 \\
\hline \multirow[t]{3}{*}{$40: 60$} & $50: 50$ & 559 & 702 & 630 & 706 & 793 & 749 \\
\hline & $25: 75$ & 559 & 701 & 626 & 705 & 793 & 749 \\
\hline & $0: 100$ & 559 & 700 & 621 & 705 & 793 & 748 \\
\hline SEM & & 0.21 & 0.13 & 0.10 & 0.33 & 0.31 & 0.19 \\
\hline \multicolumn{8}{|c|}{ Comparison } \\
\hline & $\mathrm{R}: \mathrm{C}$ ratio & $<0.01$ & $<0.01$ & $<0.01$ & $<0.01$ & $<0.01$ & $<0.01$ \\
\hline & $60: 40$ & $540^{c}$ & $677^{c}$ & $609^{c}$ & $677^{c}$ & $772^{c}$ & $724^{c}$ \\
\hline & $50: 50$ & $552^{b}$ & $689^{b}$ & $621^{b}$ & $692^{b}$ & $778^{b}$ & $735^{b}$ \\
\hline & $40: 60$ & $559^{a}$ & $701^{a}$ & $631^{a}$ & $706^{a}$ & $793^{a}$ & $750^{a}$ \\
\hline SBN & CWYW ratio & 0.86 & $<0.01$ & 0.02 & 0.50 & 0.32 & 0.23 \\
\hline & $100: 0$ & 551 & $692^{a}$ & $622^{a}$ & 693 & 781 & 738 \\
\hline & $75: 25$ & 551 & $689 \mathrm{ab}$ & $620^{a b}$ & 692 & 783 & 737 \\
\hline & $50: 50$ & 551 & $688^{a b}$ & $620^{a b}$ & 690 & 782 & 737 \\
\hline & $25: 75$ & 551 & $688^{a b}$ & $620^{a b}$ & 691 & 780 & 735 \\
\hline & $0: 100$ & 549 & $686^{c}$ & $617^{c}$ & 692 & 779 & 735 \\
\hline & hteraction & 0.95 & 0.28 & 0.78 & 0.92 & 0.73 & 0.94 \\
\hline
\end{tabular}

$\overline{\mathrm{a}-\mathrm{c}}$ Value on the same row with different superscripts differ $(p<0.05) ;{ }^{1} \mathrm{R}: \mathrm{C}=$ roughage to concentrate ratio

2 SBM:CWYW = replacing soybean meal with citric waste fermented yeast waste ratio.

\subsection{Ruminal $\mathrm{NH}_{3}-\mathrm{N}, \mathrm{pH}$ and Protozoal Population}

Table 4 shows the influence of substituting SBM for CWYW in combination with the $\mathrm{R}: \mathrm{C}$ ratio on the ruminal $\mathrm{NH}_{3}-\mathrm{N}, \mathrm{pH}$, and population of protozoa. There was no interaction effect between factors on the ruminal $\mathrm{NH}_{3}-\mathrm{N}, \mathrm{pH}$, and protozoal population $(p>0.05)$. The SBM:CWYW ratio of 0:100 significantly increased the impact $(p<0.05)$ on ruminal $\mathrm{NH}_{3}-\mathrm{N}$ at $2 \mathrm{~h}, 4 \mathrm{~h}$, and the mean value with the highest values of $17.6,19.4$ and $18.2 \mathrm{mg} / \mathrm{dL}$, respectively. However, the $\mathrm{pH}$ and protozoal population were not affected by the SBM:CWYW ratio $(p>0.05)$. 
Table 4. Effect of R:C ratio level combined with SBM:CWYW ratio level on ruminal $\mathrm{NH}_{3}-\mathrm{N}$, pH and protozoal population.

\begin{tabular}{|c|c|c|c|c|c|c|c|c|c|c|}
\hline \multirow{2}{*}{$\mathrm{R}: \mathrm{C}^{1}$} & \multirow{2}{*}{ SBM:CWYW ${ }^{2}$} & \multicolumn{3}{|c|}{$\mathrm{NH}_{3}-\mathrm{N}(\mathrm{mg} / \mathrm{dL})$} & \multicolumn{3}{|c|}{$\mathrm{pH}$} & \multicolumn{3}{|c|}{ Protozoal Count $\left(\times 10^{5}\right.$ cell $\left./ \mathrm{mL}\right)$} \\
\hline & & $2 \mathrm{~h}$ & $4 \mathrm{~h}$ & Mean & $2 \mathrm{~h}$ & $4 \mathrm{~h}$ & Mean & $2 \mathrm{~h}$ & $4 \mathrm{~h}$ & Mean \\
\hline & $100: 0$ & 15.4 & 16.5 & 16.4 & 7.04 & 6.99 & 7.01 & 3.8 & 3.9 & 3.8 \\
\hline & $75: 25$ & 14.8 & 15.8 & 16.0 & 7.10 & 7.04 & 7.07 & 3.8 & 3.9 & 3.8 \\
\hline \multirow[t]{5}{*}{$60: 40$} & $50: 50$ & 15.6 & 16.6 & 16.6 & 7.11 & 7.05 & 7.08 & 3.7 & 4.0 & 3.9 \\
\hline & $25: 75$ & 15.7 & 16.7 & 17.2 & 7.11 & 7.04 & 7.07 & 3.8 & 3.9 & 3.8 \\
\hline & $0: 100$ & 16.0 & 17.1 & 17.2 & 7.10 & 7.04 & 7.08 & 3.7 & 4.0 & 3.9 \\
\hline & $100: 0$ & 16.7 & 17.0 & 16.8 & 6.97 & 6.93 & 6.94 & 3.7 & 4.1 & 3.9 \\
\hline & $75: 25$ & 16.7 & 17.8 & 17.6 & 6.97 & 6.93 & 6.95 & 3.7 & 4.1 & 3.9 \\
\hline \multirow[t]{5}{*}{$50: 50$} & $50: 50$ & 17.3 & 17.7 & 17.4 & 7.00 & 6.93 & 6.95 & 3.7 & 4.1 & 3.9 \\
\hline & $25: 75$ & 17.8 & 18.4 & 17.9 & 6.97 & 6.94 & 6.95 & 3.6 & 4.2 & 3.8 \\
\hline & $0: 100$ & 17.8 & 18.9 & 18.3 & 6.97 & 6.92 & 6.94 & 3.7 & 4.2 & 4.0 \\
\hline & $100: 0$ & 17.9 & 18.8 & 18.8 & 6.97 & 6.73 & 6.84 & 3.8 & 4.3 & 4.0 \\
\hline & $75: 25$ & 18.6 & 19.6 & 19.3 & 6.97 & 6.73 & 6.84 & 3.8 & 4.3 & 4.0 \\
\hline \multirow{3}{*}{$40: 60$} & $50: 50$ & 19.2 & 20.2 & 19.7 & 6.97 & 6.74 & 6.85 & 3.7 & 4.3 & 4.0 \\
\hline & $25: 75$ & 19.3 & 20.4 & 19.8 & 6.97 & 6.73 & 6.84 & 3.7 & 4.3 & 4.0 \\
\hline & $0: 100$ & 19.3 & 20.4 & 19.8 & 6.99 & 6.74 & 6.87 & 3.9 & 4.3 & 4.1 \\
\hline SEM & & 0.42 & 0.45 & 0.44 & 0.04 & 0.04 & 0.06 & 0.48 & 0.07 & 0.26 \\
\hline \multicolumn{11}{|c|}{ Comparison } \\
\hline & $\mathrm{R}: \mathrm{C}$ ratio & $<0.01$ & $<0.01$ & $<0.01$ & 0.04 & $<0.01$ & $<0.01$ & 0.43 & $<0.01$ & 0.92 \\
\hline & $60: 40$ & $15.4^{\mathrm{b}}$ & $16.6^{c}$ & $16.0^{\mathrm{C}}$ & $7.09^{\mathrm{a}}$ & $7.03^{a}$ & $7.06^{\mathrm{a}}$ & 3.8 & $3.9^{b}$ & 3.9 \\
\hline & $50: 50$ & $16.9^{b}$ & $17.9^{b}$ & $17.4^{\mathrm{b}}$ & $6.97^{b}$ & $6.90^{b}$ & $6.94^{b}$ & 3.7 & $4.1^{b}$ & 3.9 \\
\hline & $40: 60$ & $18.9^{a}$ & $19.8^{\mathrm{a}}$ & $19.4^{\mathrm{a}}$ & $6.96^{\mathrm{b}}$ & $6.83^{c}$ & $6.85^{c}$ & 3.6 & $4.2^{\mathrm{a}}$ & 3.8 \\
\hline SBN & CWYW ratio & 0.02 & 0.01 & 0.02 & 0.98 & 0.93 & 0.96 & 0.98 & 0.58 & 0.98 \\
\hline & 100:0 & $16.4^{\mathrm{c}}$ & $17.5^{\mathrm{c}}$ & $16.9^{c}$ & 7.02 & 6.90 & 6.93 & 3.7 & 4.1 & 3.9 \\
\hline & $75: 25$ & $16.9^{b c}$ & $17.6^{\mathrm{bc}}$ & $17.2^{b c}$ & 7.01 & 6.90 & 6.95 & 3.7 & 4.1 & 3.9 \\
\hline & $50: 50$ & $17.2^{a b c}$ & $18.3^{a b c}$ & $17.6^{\mathrm{abc}}$ & 7.01 & 6.90 & 6.95 & 3.7 & 4.1 & 3.9 \\
\hline & $25: 75$ & $17.4^{\mathrm{ab}}$ & $18.5^{a b}$ & $18.0^{\mathrm{ab}}$ & 7.00 & 6.90 & 6.96 & 3.7 & 4.1 & 3.9 \\
\hline & 0:100 & $17.6^{\mathrm{a}}$ & $19.4^{\mathrm{a}}$ & $18.2^{\mathrm{a}}$ & 6.98 & 6.88 & 6.96 & 3.8 & 4.2 & 4.0 \\
\hline & nteraction & 0.54 & 0.70 & 0.63 & 0.99 & 0.98 & 0.99 & 0.99 & 0.77 & 0.99 \\
\hline
\end{tabular}

${ }^{\mathrm{a}-\mathrm{c}}$ Value on the same row with different superscripts differ $(p<0.05) ;{ }^{1} \mathrm{R}: \mathrm{C}=$ roughage to concentrate ratio. ${ }^{2} \mathrm{SBM}: \mathrm{CWYW}=$ replacing soybean meal with citric waste fermented yeast waste ratio.

Additionally, the $\mathrm{R}: \mathrm{C}$ ratio of 40:60 significantly increased $(p<0.01)$ the ruminal $\mathrm{NH}_{3}$ $\mathrm{N}$ at $2 \mathrm{~h}, 4 \mathrm{~h}$, and the mean value and the values, which were $18.9,19.8$, and $19.4 \mathrm{mg} / \mathrm{dL}$, respectively. The ruminal $\mathrm{pH}$ at $2 \mathrm{~h}, 4 \mathrm{~h}$, and the mean values ranged from 6.73 to 7.10 , which were reduced $(p<0.01)$ by the R:C ratio of 40:60 group. The protozoal population at $2 \mathrm{~h}$ and the mean values remained unchanged $(p>0.05)$, while the protozoal population at $4 \mathrm{~h}$ was increased $(p<0.05)$ by the R:C ratio of $40: 60$.

\subsection{In Vitro VFAs Concentration}

Table 5 shows the influence of substituting SBM for CWYW in combination with the $\mathrm{R}: \mathrm{C}$ ratio level on in vitro VFAs. An interaction effect was not detected between factors on the in vitro VFA concentration $(p>0.05)$. In addition, the SBM:CWYW ratio did not impact the in vitro VFA profile $(p>0.05)$. However, the total VFA at $2 \mathrm{~h}, 4 \mathrm{~h}$, and the mean value were significantly increased $(p<0.01)$ by decreasing the $\mathrm{R}: \mathrm{C}$ ratio to $40: 60$. Propionate (C3) at $2 \mathrm{~h}, 4 \mathrm{~h}$, and the mean value were significantly increased $(p<0.01)$ by decreasing the $\mathrm{R}: \mathrm{C}$ ratio to 40:60. Furthermore, the decrease in the $\mathrm{R}: \mathrm{C}$ ratio to 40:60 decreased $(p<0.01)$ acetate (C2) at $2 \mathrm{~h}, 4 \mathrm{~h}$, and the mean value. The $\mathrm{C} 2$ to $\mathrm{C} 3$ ratio $(\mathrm{C} 2: \mathrm{C} 3)$ at $2 \mathrm{~h}, 4 \mathrm{~h}$, and the mean value were decreased $(p<0.01)$ by decreasing the R:C ratio, while butyrate $(C 4)$ remained similar $(p>0.05)$. 
Table 5. Effect of R:C ratio level combined with SBM:CWYW ratio level on in vitro volatile fatty acids (VFAs).

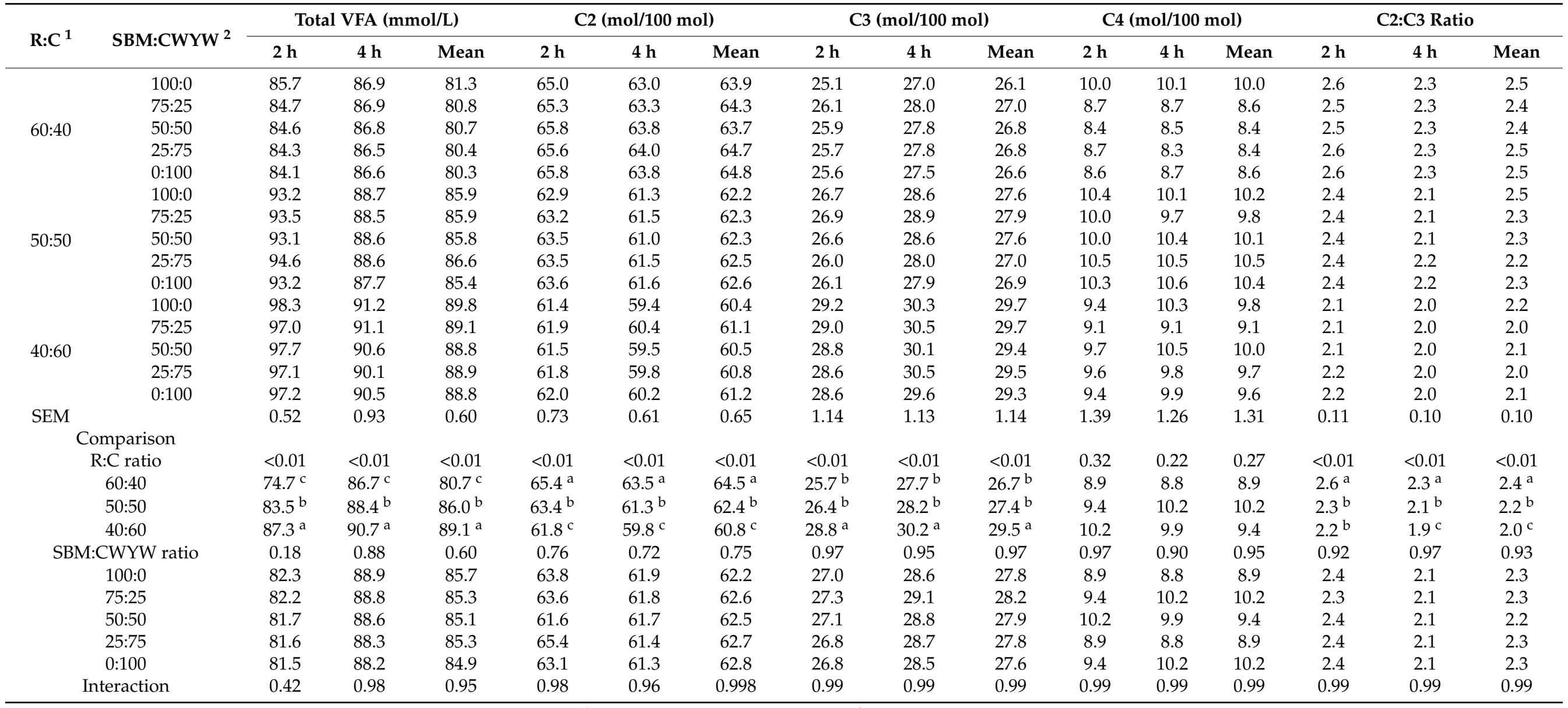

${ }^{\mathrm{a}-\mathrm{c}}$ Value on the same row with different superscripts differ $(p<0.05),{ }^{1} \mathrm{R}: \mathrm{C}=$ roughage to concentrate ratio. ${ }^{2}$ SBM:CWYW $=$ replacing soybean meal with citric waste fermented yeast waste ratio. 


\section{Discussion}

\subsection{Dietary Chemical Composition}

In this study, the CP content of non-fermented citric waste was $110 \mathrm{~g} / \mathrm{kg} \mathrm{DM}$, which was comparable to the result reported by Silva et al. [5] (79.3-110.8 g/ $/ \mathrm{kg}$ DM of CP). However, a lower content of CP of $61.1 \mathrm{~g} / \mathrm{kg}$ DM in citric waste was found in a study of Tanpong et al. [7]. The NDF and ADF contents in non-fermented citric waste were lower than in the report by Uriyapongson et al. [6] (861.3 and $197.4 \mathrm{~g} / \mathrm{kg} \mathrm{DM}$, respectively). This was probably due to the differences between raw materials used for citric production, such as the variety, age of harvest, and soil fertilizer [24,25]. In addition, the processing of citric production might influence the different nutrient compositions [5].

The CP content in the yeast waste used in this study was $315 \mathrm{~g} / \mathrm{kg} \mathrm{DM}$, which is close to the result from Bátori et al. [26], who reported $320 \mathrm{~g} / \mathrm{kg}$ DM. However, the CP content in yeast waste could vary from about 182.5 to $296 \mathrm{~g} / \mathrm{kg}$ DM [10,27-29]. This might be caused by substrate used in ethanol production, heat from the fermentation process, yeast strain, and freshness of the yeast stillage, which is a complex medium [26,30,31].

After improving the citric acid waste quality by yeast waste fermentation, CWYW was found to have increased $\mathrm{CP}$ to $535 \mathrm{~g} / \mathrm{kg}$ DM when compared with non-fermented citric waste. This could be due yeast waste containing high protein content and being rich in essential amino acids $[9,10]$. In addition, the inclusion of media solution containing urea in the CWYW fermented product during the fermentation process might enhance the $\mathrm{CP}$ content [3]. Fiber contents were reduced when citric acid waste was fermented with yeast waste. Similarly, Suntara et al. [32] indicated that some strains of yeast could produce cellulolytic enzymes to break down fiber in plant materials. Furthermore, the fermentation process with a media containing urea as an alkaline agent might degrade the structure fiber of CWYW and lead to the fiber structure decreasing [33].

\subsection{Kinetics and Cumulative Production of Gas}

Yeast waste rich in S. cerevisiae could promote the microorganism in the rumen and improve the incubated substrate's digestibility, thus improving the kinetics of gas production and increasing the total production of gas [34]. However, in this study, the kinetics of gas was not changed by the SBM:CWYW ratio. This is probably due to the fermentation of protein not leading to the production of gas [35]. This agreed with the results of Cherdthong et al. [10], who stated that the gas and fermentation kinetics was not changed by the substitution of soybean meal with yeast waste.

Moreover, soluble fraction (a), rate of gas production (c), potential extent of gas production $(|\mathrm{a}|+\mathrm{b})$, and the cumulative production of gas were significantly affected by the $\mathrm{R}: \mathrm{C}$ ratio. The addition of a high concentration ratio contributes to an improvement in the rate of fermentation and soluble fraction of the rumen [34]. Starch degradation is an important factor in regulating energy utilization for the growth of rumen microorganisms, increasing the rumen population, and increasing digestion [36]. The potential extent of gas production $(|\mathrm{a}|+\mathrm{b})$ is known to be essentially the result of the carbohydrates fermented into acetate, propionate, and butyrate [37].

The present results demonstrated that the intercept value of (a) was negative in this study. This was a result of the delay in ruminal microbial growth of the substrates during the early stage of incubation. The data show that there is a lag period after the soluble part of the substrate is ingested but before the cell walls are fermented [38,39]. Several researchers $[35,40]$ have also stated that, when using mathematical models to match the kinetics of gas output, there were negative values for different substrates. It is understood that it is possible to use the absolute value of $\mathrm{a},(|\mathrm{a}|)$, to define the ideal fermentation of the soluble fraction. In this experiment, the absolute gas production was the highest for the $\mathrm{R}: \mathrm{C}$ ratio of 40:60. The soluble fraction makes it easy for rumen microbes to bind and contribute to the greater production of gas [41]. The results revealed that the insoluble fraction (b) at the $\mathrm{R}: \mathrm{C}$ ratio of 60:40 was significantly the highest value. The high fiber in feed had an effect of the increase in (b), which increases the polysaccharides and activities of 
glycoside hydrolase against lignified plant tissues [3]. Particularly, the NDF degradability was substantially associated with the NDF fraction. Similarly, Phesatcha et al. [34] revealed that (b) of gas production increased as the ratio of concentrates in the diet decreased.

\subsection{In Vitro Digestibility}

The yeast $S$. cerevisiae can scavenge the accessible oxygen to support metabolic activity, thus reducing the ruminal redox potential and stimulating the ruminal microbes to have a higher rate of feed digestion. This improves the digestibility of nutrients [34]. In addition, the findings of Cherdthong et al. [11] showed that $100 \%$ of yeast waste could be used to replace SBM as a source of protein in concentrated diets without detrimental effects on digestibility. The present results indicated that CWYW can replace SBM at up to $75 \%$ without a negative impact on IVDMD and IVOMD.

During its metabolic activities, S. cerevisiae may be responsible for secreting extracellular enzymes into the citric waste mash, such as lignocellulose peroxidase, lignin peroxidase, cellulase, and hemicellulose [32,42]. This results in yeast proliferation. Additionally, this could happen because the alkaline agents (ammonium hydroxide; $\mathrm{NH}_{4} \mathrm{OH}$ ) produced from urea during the fermentation process of CWYW cause the hemicellulose-lignin complex in citric waste to swell [33]. The concentrated alkaline agents can physically swell structural fibers by chemically degrading their ester bonds [43]. This could help enable the extracellular enzymes from S. cerevisiae to attack the structural carbohydrates more easily and increase the degradability of CWYW.

However, replacement with SBM:CWYW at up to 100\% decreased IVDMD at $24 \mathrm{~h}$ and the mean value. This could be due to the structural carbohydrates content in the CWYW negatively affecting digestibility in vitro. Uriyapongson et al. [6] reported that the use of citric waste at more than $10 \%$ in the diet results in the digestibility decreasing because of the high fiber content. It was concluded that changes in cell-wall composition involving structural carbohydrate contents in CWYW restricted the possible degree of digestion, while chemical factors other than the crystalline or physical nature of the fiber limited the rate of digestion [44].

The R:C ratio of 40:60 improved the in vitro digestibility. This may have been due to increased levels of concentrate, which would supply energy that is more readily available, thereby improving the subsequent degradability by ruminal microbes. The concentrate diet has a pronounced stimulatory effect on the ruminal microflora that is achieved more readily from carbohydrates than from forages in the rumen [45]. These studies agree with Cherdthong et al. [12], who demonstrated that when the fiber value was reduced, particularly with a higher concentrate level, ruminal microbe activity could be encouraged [46]. However, in buffalo, the in vitro organic matter digestibility (IVOMD) increased with the increase in concentrate in the diet, while the cumulative gas production showed an irregular trend and was not closely correlated to digested OM [47].

\subsection{In Vitro Ruminal $\mathrm{NH}_{3}-\mathrm{N}$ Concentration and Ruminal $\mathrm{pH}$}

In the present study, the ruminal $\mathrm{NH}_{3}-\mathrm{N}$ concentration was increased with higher levels of concentrate diet and levels of CWYW used to replace soybean meal. This is probably due to CWYW containing yeast waste, which has a high protein content of $315 \mathrm{~g} / \mathrm{kg}$ DM. Thus, substantial increases in $\mathrm{NH}_{3}-\mathrm{N}$ concentrations occur in response to the microbial degradation of yeast cells $[48,49]$. Additionally, it could be due to the ability to provide stimulatory factors and even protein $[50,51]$ to ruminal bacteria, or by changing in the abundance of microbes with proteolytic activity [52].

Another reason is likely the NPN-urea level in CWYW, which was higher than in previous studies by Polyorach et al. [3], where increased levels of urea-N in feed resulted in an increase in ruminal $\mathrm{NH}_{3}-\mathrm{N}$ concentration from the dissolution of urea. The rapid hydrolysis of $\mathrm{NPN}$-urea to rumen $\mathrm{NH}_{3}-\mathrm{N}$ by microbial enzymes is another possible cause in the present study [10]. The amount of $\mathrm{N}$ actually digested in the rumen increased as the proportion of concentrate in the diet increased, which is likely to be a key explanation 
for enhancing in the concentration of $\mathrm{NH}_{3}-\mathrm{N}$ in the rumen [14]. Additionally, decreasing the $\mathrm{R}: \mathrm{C}$ ratio from 60:40 to 40:60 in the diet increased the ruminal $\mathrm{NH}_{3}-\mathrm{N}$ concentration. Similarly, Suriyapha et al. [46] and Matra et al. [53] revealed that the concentrations of rumen $\mathrm{NH}_{3}-\mathrm{N}$ increased significantly with a decreasing $\mathrm{R}: \mathrm{C}$ ratio.

The ruminal $\mathrm{pH}$ is an important parameter that reflects the internal homeostasis of the rumen environment. Normally, ruminants have a highly balanced ecology for preserving a ruminal $\mathrm{pH}$ range of 6.0-7.0 [14]. The yeast motivates lactate users and enhances their population, but it also serves as a contender with the producers of lactate [54]. However, the data of this study revealed that the ruminal $\mathrm{pH}$ was not changed by the influence of the SBM:CWYW ratio. Similarly, Cherdthong et al. [10] found that $100 \%$ of yeast waste used to replace soybean meal did not change the ruminal $\mathrm{pH}$ in vitro, and saw no negative impact on the ruminal $\mathrm{pH}$ in Thai native bulls [11]. Additionally, ruminal $\mathrm{pH}$ at $4 \mathrm{~h}$ and the mean value were decreased by the higher $\mathrm{R}: \mathrm{C}$ ratio. This agrees with Cherdthong et al. [12], who reported that a high ratio of concentrate diet usually results in a significant drop in ruminal $\mathrm{pH}$, which decreases the activity of cellulolytic bacteria and slows digestion.

\subsection{In Vitro Protozoal Population}

This study revealed that the number of protozoa did not change when changing the SBM:CWYW ratio. However, the protozoal counts at $4 \mathrm{~h}$ was increased by the highest concentrate ratio, which agrees with Cherdthong et al. [12]. This might have happened because of the role of protozoal in starch utilization, which progressively increase when a carbohydrate with fast fermentation is added [34]. In contrast, Van Soest [55] demonstrated that feeding over a certain level of concentrate diet could reduce the population of protozoa. Suriyapha et al. [46] and Matra et al. [53] revealed that an experimental diet with an R:C ratio higher than 30:70 decreased the protozoal population. This is probably due to the increased concentrate diet leading to a high fermentation rate, which results in a lower $\mathrm{pH}$ that is unsuitable for the rumen ecology and decreases protozoal populations [3].

\subsection{In Vitro VFAs}

When replacing SBM with CWYW at up to $100 \%$, the concentration of VFA and VFA profiles could be maintained. Similar results on VFA production between CWYW and SMB indicate that CWYW has similar nutritional quality and that it could be comparable to SBM when used to enhance ruminal end-products. Increased concentrate levels enhanced in vitro VFA, which could be supported by the fact that a concentrate diet contains a fraction of highly degradable carbohydrates, particularly starch. The high level of starch in concentrate diet appeared to increase the total VFA and $\mathrm{C} 3$, while $\mathrm{C} 2$ and the $\mathrm{C} 2: \mathrm{C} 3$ ratio were decreased with an expanding concentrate level $[45,56]$.

In particular, C3 is obtained by the fermentation of soluble carbohydrates with more concentrate diet by ruminal bacteria activity [57]. This agrees with Cherdthong et al. [11], who also reported that the fermentation of a high concentrate level resulted in a greater molar concentration of ruminal C3. In addition, Phesatcha et al. [34] reported that increasing the ratio of a concentrate diet to $80 \%$ could increase VFA and C3, whereas $\mathrm{C} 2$ and the $\mathrm{C2}: \mathrm{C} 3$ ratios decreased.

\section{Conclusions}

Citric waste can improve the nutritional values by being fermented with yeast waste and appropriate media solutions. No interaction effect was found between the R:C ratio and SBM:CWYW for all parameters. CWYW could be substituted for SBM in concentrate diets at up to $75 \%$ by without negative impact on gas kinetics, ruminal parameters, and in vitro digestibility. In addition, the R:C ratio of 40:60 could be beneficial for gas kinetics, ruminal ecology, digestibility, volatile fatty acids, and propionic acid concentration. However, more in vivo trials should be conducted in order to determine the success of animal production. 
Author Contributions: Planning and design of the study, C.S. (Chaichana Suriyapha) and A.C.; conducting and sampling, C.S. (Chaichana Suriyapha), A.C. and C.S. (Chanon Suntara); sample analysis, C.S. (Chaichana Suriyapha), A.C. and C.S.(Chanon Suntara); statistical analysis, C.S. (Chaichana Suriyapha) and A.C.; manuscript drafting, C.S. (Chaichana Suriyapha), A.C. and C.S. (Chanon Suntara); manuscript editing and finalizing, C.S. (Chaichana Suriyapha), A.C. and C.S. (Chanon Suntara); and S.P.; All authors have read and agreed to the published version of the manuscript.

Funding: The authors express their most sincere gratitude to the Research Program on the Research and Development of Winged Bean Root Utilization as Ruminant Feed, Increase Production Efficiency and Meat Quality of Native Beef and Buffalo Research Group and Research and Graduate Studies, Khon Kaen University (KKU), and Office of National Higher Education Science Research and Innovation Policy Council through the Program Management Unit for Competitiveness (PMUC) (contract grant C10F640078). Mr. Chaichana Suriyapha was granted by Animal Feed Inter Trade Co., Ltd. and Thailand Science Research and Innovation (TSRI) through the Researcher for Industry (RRi) program (contract grant PHD62I0021).

Institutional Review Board Statement: The study was conducted under approval procedure no. IACUC-KKU-27/64 of Animal Ethics and Care issued by Khon Kaen University.

Informed Consent Statement: Not applicable.

Data Availability Statement: Not applicable.

Acknowledgments: The authors would like to express our sincere thanks to the KSL Green Innovation Public Co. Limited, Thailand and the Tropical Feed Resources Research and Development Center (TROFREC), Department of Animal Science, Faculty of Agriculture, Khon Kaen University $(\mathrm{KKU})$ for the use of the research facilities.

Conflicts of Interest: The authors declare no conflict of interest.

\section{References}

1. Tsinas, A.; Tzora, A.; Peng, J. Alternative protein sources to soybean meal in pig diets. J. Food. Agric. Environ. 2014, 12, 655-660.

2. Wanapat, M.; Rowlinson, P. Nutrition and feeding of swamp buffalo: Feed resources and rumen approach. Ital. J. Anim. Sci. 2007, 6, 67-73. [CrossRef]

3. Polyorach, S.; Wanapat, M.; Cherdthong, A. Influence of yeast fermented cassava chip protein (YEFECAP) and roughage to concentrate ratio on ruminal fermentation and microorganisms using in vitro gas production technique. Asian-Australas. J. Anim. Sci. 2014, 27, 36-45. [CrossRef] [PubMed]

4. Ajila, C.M.; Brar, S.K.; Verma, M.; Tyagi, R.D.; Godbout, S.; Valéro, J.R. Bio-processing of agro-byproducts to animal feed. Crit. Rev. Biotechnol. 2012, 32, 382-400. [CrossRef] [PubMed]

5. Silva, C.E.; Gois, G.N.; Silva, L.M.; Almeida, R.M.; Abud, A.K. Citric waste saccharification under different chemical treatments. Acta Sci. Technol. 2015, 37, 387-395. [CrossRef]

6. Uriyapongson, S.; Wachirapakorn, C.; Nananukraw, C.; Phoemchalard, C.; Panatuk, J.; Tonuran, W. Digestibility and performance of buffalo fed total mixed ration with different levels of citric waste. Buffalo Bull. 2013, 32, 829-833.

7. Tanpong, S.; Cherdthong, A.; Tengjaroenkul, B.; Tengjaroenkul, U.; Wongtangtintharn, S. Evaluation of physical and chemical properties of citric acid industrial waste. Trop. Anim. Health Prod. 2019, 51, 2167-2174. [CrossRef] [PubMed]

8. Polyorach, S.; Wanapat, M.; Wanapat, S. Enrichment of protein content in cassava (Manihot esculenta Crantz) by supplementing with yeast for use as animal feed. Emir. J. Food Agric. 2013, 25, 142-149. [CrossRef]

9. Díaz, A.; Ranilla, M.J.; Saro, C.; Tejido, M.L.; Pérez-Quintana, M.; Carro, M.D. Influence of increasing doses of a yeast hydrolyzate obtained from sugarcane processing on in vitro rumen fermentation of two different diets and bacterial diversity in batch cultures and rusitec fermenters. Anim. Feed Sci. Technol. 2017, 232, 129-138. [CrossRef]

10. Cherdthong, A.; Prachumchai, R.; Supapong, C.; Khonkhaeng, B.; Wanapat, M.; Foiklang, S.; Milintawisamai, N.; Gunun, N.; Gunun, P.; Chanjula, P.; et al. Inclusion of yeast waste as a protein source to replace soybean meal in concentrate mixture on ruminal fermentation and gas kinetics using in vitro gas production technique. Anim. Prod. Sci. 2018, 59, 1682-1688. [CrossRef]

11. Cherdthong, A.; Sumadong, P.; Foiklang, S.; Milintawisamai, N.; Wanapat, M.; Chanjula, P.; Gunun, N.; Gunun, P. Effect of post-fermentative yeast biomass as a substitute for soybean meal on feed utilization and rumen ecology in Thai native beef cattle. J. Anim. Feed Sci. 2019, 28, 238-243. [CrossRef]

12. Cherdthong, A.; Wanapat, M.; Kongmun, P.; Pilajun, R.; Khejornsart, P. Rumen fermentation, microbial protein synthesis and cellulolytic bacterial population of swamp buffaloes as affected by roughage to concentrate ratio. J. Anim. Vet. Adv. 2010, 9, 1667-1675. [CrossRef]

13. Cherdthong, A.; Wanapat, M.; Wachirapakorn, C. Influence of urea calcium mixture supplementation on ruminal fermentation characteristics of beef cattle fed on concentrates containing high levels of cassava chips and rice straw. Anim. Feed Sci. Technol. 2011, 163, 43-51. [CrossRef] 
14. Wanapat, M.; Gunun, P.; Anantasook, N.; Kang, S. Changes of rumen pH, fermentation and microbial population as influenced by different ratios of roughage (rice straw) to concentrate in dairy steers. J. Agric. Sci. 2014, 152, 675-685. [CrossRef]

15. Association of Official Analytical Chemists. Official Methods of Analysis, 16th ed.; Association of Official Analytical Chemists: Arlington, VA, USA, 1995.

16. Van Soest, P.J.; Robertson, J.B.; Lewis, B.A. Methods for dietary fiber neutral detergent fiber, and non-starch polysaccharides in relation to animal nutrition. J. Dairy Sci. 1991, 74, 3583-3597. [CrossRef]

17. Makkar, H.P.S.; Blumme, M.; Becker, K. Formation of complexes between polyvinyl pyrrolidones or polyethylene glycols and tannins, and their implication in gas production and true digestibility in in vitro techniques. Br. J. Nutr. 1995, 73, 897-913. [CrossRef]

18. Ørskov, E.R.; McDonald, I. The estimation of protein degradability in the rumen from incubation measurements weighted according to rate of passage. J. Agric. Sci. 1979, 92, 499-503. [CrossRef]

19. Samuel, M.; Sagathewan, S.; Thomus, J.; Mathen, G. An HPLC method for estimation of volatile fatty acids of rumen fluid. Indian J. Anim. Sci. 1997, 67, 805-807.

20. Galyean, M. Laboratory Procedure in Animal Nutrition Research; Department of Animal and Range Sciences, New Mexico State University: Las Cruces, NM, USA, 1989.

21. Tilley, J.M.A.; Terry, R.A. A two-stage technique for the digestion of forage crops. J. Br. Grassl. Soc. 1963, 18, 104-111. [CrossRef]

22. SAS (Statistical Analysis System). SAS/STAT User's Guide, 4th ed.; Statistical Analysis Systems Institute, Version 9; SAS Institute Inc.: Cary, NC, USA, 2013.

23. Steel, R.G.D.; Torrie, J.H. Principles and Procedures of Statistics: A Biometerial Approach, 2nd ed.; McGraw-Hill: New York, NY, USA, 1980.

24. Shewfelt, R.L. Sources of variation in the nutrient content of agricultural commodities from the farm to the consumer. J. Food Qual. 1990, 13, 37-54. [CrossRef]

25. Haile, E.; Njonge, F.K.; Asgedom, G.; Gicheha, M. Chemical composition and nutritive value of agro-industrial by-products in ruminant nutrition. Open J. Anim. Sci. 2017, 7, 8-18. [CrossRef]

26. Bátori, V.; Ferreira, J.A.; Taherzadeh, M.J.; Lennartsson, P.R. Ethanol and protein from ethanol plant by-products using edible fungi Neurospora intermedia and Aspergillus oryzae. Biomed. Res. Int. 2015, 2015, 1-10. [CrossRef]

27. Mumtaz, S.; Sheikh, M.A.; Iqbal, T.; Rehman, K.; Rashid, S. Bioconversion of distillery sludge (treated) to lysine and its biological evaluation. Int. J. Agri. Biol. 2000, 2, 274-277.

28. Sharif, M.; Shahzad, M.A.; Rehman, S.; Khan, S.; Ali, R.; Khan, M.L.; Khan, K. Nutritional evaluation of distillery sludge and its effect as a substitute of canola meal on performance of broiler chickens. Asian-Australas. J. Anim. Sci. 2012, 25, 401-409. [CrossRef]

29. Sharif, M.; Shoaib, M.; Saif Ur Rehman, M.; Fawwad, A.; Asif, J. Use of distillery yeast sludge in poultry: A review. J. Agric. Sci. 2016, 6, 242-256.

30. Azhara, S.H.M.; Abdullaab, R.; Jamboa, S.A.; Marbawia, H.; Gansaua, J.A.; Faika, A.A.M.; Rodriguesc, K.F. Yeasts in sustainable bioethanol production: A review. Biochem. Biophys. Rep. 2017, 10, 52-61.

31. Khan, M.U.; Shariati, M.A.; Kadmi, Y.; Elmsellem, H.; Majeed, M.; Khan, M.R.; Fazel, M.; Rashidzadeh, S. Design, development and performance evaluation of distillery yeast sludge dryer. Process. Saf. Environ. Prot. 2017, 111, 733-739. [CrossRef]

32. Suntara, C.; Cherdthong, A.; Uriyapongson, S.; Wanapat, M.; Chanjula, P. Comparison effects of ruminal crabtree-negative yeasts and crabtree-positive yeasts for improving ensiled rice straw quality and ruminal digestion using in vitro gas production. $J$. Fungi. 2020, 6, 109. [CrossRef] [PubMed]

33. Mapato, C.; Wanapat, M.; Cherdthong, A. Effect of urea treatment of straw and dietary level of vegetable oil on lactating dairy cows. Trop. Anim. Health Prod. 2010, 42, 1635-1642. [CrossRef] [PubMed]

34. Phesatcha, K.; Phesatcha, B.; Wanapat, M.; Cherdthong, A. Roughage to concentrate ratio and Saccharomyces cerevisiae inclusion could modulate feed digestion and in vitro ruminal fermentation. Vet. Sci. 2020, 7, 151. [CrossRef] [PubMed]

35. Khazaal, K.; Dentinho, M.T.; Riberiro, J.M.; Ørskov, E.R. A comparison of gas production during incubation with rumen contents in vitro and nylon bag degradability as predictors of the apparent digestibility in vivo and the voluntary intake of hays. Anim. Sci. 1993, 57, 105-112. [CrossRef]

36. Nocek, J.E.; Tamminga, S. Site of digestion of starch in the gastrointestinal tract of dairy cows and its effect on milk and composition. J. Dairy Sci. 1991, 74, 3598-3629. [CrossRef]

37. Getachew, G.; Blummel, M.; Makkar, H.P.S.; Becker, K. In vitro gas measuring techniques for assessment of nutritional quality of feeds: A review. Anim. Feed Sci. Technol. 1998, 72, 261-281. [CrossRef]

38. Chanthakhoun, V.; Wanapat, M. The in vitro gas production and ruminal fermentation of various feeds using rumen liquor from swamp buffalo and cattle. Asian J. Anim. Vet. Adv. 2012, 7, 54-60. [CrossRef]

39. Soriano, A.P.; Mamuad, L.L.; Kim, S.H.; Choi, Y.J.; Jeong, C.D.; Bae, C.D.; Chang, M.B.; Lee, S.S. Effect of Lactobacillus mucosae on in vitro rumen fermentation characteristics of dried brewers grain, methane production and bacterial diversity. Asian-Australas. J. Anim. Sci. 2014, 27, 1562-1570. [CrossRef] [PubMed]

40. Blummel, M.; Becker, K. The degradability characteristics of fifty-four roughages and roughage neutral detergent fibres as described by in vitro gas production and their relationship to voluntary feed intake. Br. J. Nutr. 1997, 77, 757-768. [CrossRef]

41. Chumpawadee, S.; Sommart, K.; Vongpralub, T.; Pattarajinda, V. Nutritional evaluation of non-forage high fibrous tropical feeds for ruminant using in vitro gas production technique. Walailak J. Sci. Technol. 2005, 2, 209-218. 
42. Kricka, W.; Fitzpatrick, J.; Bond, U. Metabolic engineering of yeasts by heterologous enzyme production for degradation of cellulose and hemicellulose from biomass: A perspective. Front. Microbiol. 2014, 5, 174. [CrossRef] [PubMed]

43. Wanapat, M.; Polyorach, S.; Boonnop, K.; Mapato, C.; Cherdthong, A. Effects of treating rice straw with urea or urea and calcium hydroxide upon intake, digestibility, rumen fermentation and milk yield of dairy cows. Livest. Sci. 2009, 125, 238-243. [CrossRef]

44. Hart, F.J.; Wanapat, M. Physiology of digestion of urea-treated rice straw in swamp buffalo. Asian-Australas. J. Anim. Sci. 1992, 5, 617-622. [CrossRef]

45. Hungate, R.E. The Rumen and Its Microbes; Academic Press: New York, NY, USA, 1966.

46. Suriyapha, C.; Ampapon, T.; Viennasay, B.; Matra, M.; Wann, C.; Wanapat, M. Manipulating rumen fermentation, microbial protein synthesis, and mitigating methane production using bamboo grass pellet in swamp buffaloes. Trop. Anim. Health Prod. 2020, 52, 1609-1615. [CrossRef] [PubMed]

47. Zicarelli, F.; Calabro, S.; Piccolo, V.; D’Urso, S.; Tudisco, R.; Bovera, F.; Cutrignelli, M.I.; Infascelli, F. Diets with different forage/concentrate ratios for the Mediterranean Italian buffalo: In vivo and in vitro digestibility. Asian-Australas. J. Anim. Sci. 2008, 21, 75-82. [CrossRef]

48. Oeztuerk, H.; Schroeder, B.; Bayerbach, M.; Breves, G. Influence of living and autoclaved yeasts of Saccharomyces boulardii on in vitro ruminal microbial metabolism. J. Dairy Sci. 2005, 88, 2594-2600. [CrossRef]

49. Vyas, D.; Uwizeye, A.; Mohammed, R.; Yang, W.Z.; Walker, N.D.; Beauchemin, K.A. The effects of active dried and killed dried yeast on subacute ruminal acidosis, ruminal fermentation, and nutrient digestibility in beef heifers. J. Anim. Sci. 2014, 92, 724-732. [CrossRef]

50. Miller-Webster, T.; Hoover, W.H.; Holt, M.; Nocek, J.E. Influence of yeast culture on ruminal microbiological metabolism in continuous culture. J. Dairy Sci. 2002, 85, 2009-2014. [CrossRef]

51. Oeztuerk, H. Effect of live and autoclaved yeast cultures on ruminal fermentation in vitro. J. Anim. Feed Sci. 2009, 18, 142-150 [CrossRef]

52. Cunha, C.S.; Marcondes, M.I.; Silva, A.L.; Gionbelli, T.R.S.; Novaes, M.A.S.; Knupp, L.S.; Virginio, G.F., Jr.; Veloso, C.M. Do live or inactive yeasts improve cattle ruminal environment? R. Bras. Zootec. 2019, 48, e20180259. [CrossRef]

53. Matra, M.; Wanapat, M.; Cherdthong, A.; Foiklang, S.; Mapato, C. Dietary dragon fruit (Hylocereus undatus) peel powder improved in vitro rumen fermentation and gas production kinetics. Trop. Anim. Health Prod. 2019, 51, 1531-1538. [CrossRef]

54. Chaucheras-Durand, F.; Ameilbonne, A.; Auffret, P.; Bernard, M.; Mialon, M.M.; Duniere, L.; Forano, E. Supplementation of live yeast based feed additive in early life promotes rumen microbial colonization and fibrolytic potential in lambs. Sci. Rep. 2019, 9, 19216. [CrossRef] [PubMed]

55. Van Soest, P.J. Nutritional Ecology of the Ruminant; O\&B Books Inc.: Corvallis, OR, USA, 1982; pp. $22-39$.

56. Kang, S.; Wanapat, M.; Phesatcha, K.; Norrapoke, T.; Foiklang, S.; Ampapon, T.; Phesatcha, B. Using krabok (Irvingia malayana) seed oil and Flimingia macrophylla leaf meal as a rumen enhancer in an in vitro gas production system. Anim. Prod. Sci. 2017, 57, 327-333. [CrossRef]

57. Calsamiglia, S.; Cardozo, P.W.; Ferret, A.; Bach, A. Changes in rumen microbial fermentation are due to a combined effect of type of diet and pH. J. Anim. Sci. 2008, 86, 702-711. [CrossRef] [PubMed] 